\title{
Plants for Remedies of Diabetes Mellitus in Iran
}

\author{
Fatemeh Beiranvand $^{1}$ and Mohsen Alizadeh ${ }^{*}$
}

${ }^{1}$ Immunology Research Center, Tabriz University of Medical Sciences, Tabriz, Iran

\author{
Article Info \\ *Correspondence to: \\ Mohsen Alizadeh \\ M.alizadeh5667@gmail.com \\ Article History: \\ Received: 08 August 2019 \\ Accepted: 19 Oct 2019 \\ ePublished: 20 Nov 2019
}

Keywords: Diabetes, Diabetes mellitus, Herbal medicine, Medicinal plants, Iran

\section{Abstract}

Diabetes mellitus is a disease occurs when blood glucose is too high. Blood glucose is the main source of energy comes from the food. Insulin, a hormone made by the pancreas, helps glucose get into the cells to be used for energy. Sometimes body doesn't make enough or any insulin or doesn't use insulin well. Glucose then stays in blood and doesn't reach cells. Diabetes, various cardiovascular complications, wounds, kidney problems, and many other diseases are chronic. Natural and plant-based antioxidants are more frequently used for treatment of diabetes. Herbal medicine, Cinnamomum zeylanicum Blume, Allium sativum L., Allium cepa L., Momordica charantia L., Trigonella foenum-graecum L., Zingiber officinale Roscoe, Curcuma longa L., Silybum marianum (L.) Gaertn., Citrullus colocynthis (L.) Schrad., Aloe vera (L.) Burm.f., Camellia sinensis (L.) Kuntze, Eugenia caryophylata Thunb., Mentha pulegium L., Urtica dioica L., Teucrium polium L., Ocimum basilicum L., Matricaria chamomilla L., Cuminum cyminum L., Taraxacum officinale (L.) Weber ex F.H.Wigg., Anethum graveolens L., Anethum graveolens L., Rosmarinus officinalis L., Thymus vulgaris L., Artemisia dracunculus L., Ficus carica L., Nigella sativa L., Olea europaea L., and Vitis vinifera L. are among the phytotherapies for diabetes.

\section{How to cite this paper}

Beiranvand F and Alizadeh M. Plants for remedies of diabetes mellitus in Iran. Plant Biotechnology Persa 2019; 1(1): 36-38.

\section{Dear ediitor;}

Chronic diseases always cause human suffering and, in addition to the time spent on they, impose stupendous costs for treatment $[1,2]$. Chronic diseases have certain mechanisms that are caused and exacerbated by various

factors [1-3]. Diabetes, various cardiovascular complications, wounds, kidney problems, and many other diseases are chronic [1-3]. Diabetes is one of those diseases that has an invasive state and affects various organs such as the kidneys,

Copyright (C) 2020 The Author(s). This is an open-access article distributed under the terms of the Creative Commons Attribution License (http://creativecommons.org/licenses/by/4.0), which permits unrestricted use, distribution, and reproduction in any medium, provided the original work is properly cited. 
the heart, the brain, the ears, the eyes, the brain, and nerves and lead to complications in them. The number of people with diabetes mellitus is increasing due to population growth, urbanization, physical inactivity, obesity, and also the aging population. According to published statistics, 124 million people in the world suffer from the disease [4]. Today, herbal medicine has been found to control, prevent, and treat diseases. In this regard, natural and plant-based antioxidants are more frequently used $[5,6]$. Based on the results in Iranian pharmacopoeia and Iranian traditional and herbal medicine, Cinnamomum zeylanicum Blume, Allium sativum L., Allium cepa L., Momordica charantia L., Trigonella foenum-graecum L., Zingiber officinale Roscoe, Curcuma longa L., Silybum marianum (L.) Gaertn., Citrullus colocynthis (L.) Schrad., Aloe vera (L.) Burm.f., Camellia sinensis (L.) Kuntze, Eugenia caryophylata Thunb., Mentha pulegium L., Urtica dioica L., Teucrium polium L., Ocimum basilicum L., Matricaria chamomilla L., Cuminum cyminum L., Taraxacum officinale (L.) Weber ex F.H.Wigg., Anethum graveolens L., Anethum graveolens L., Rosmarinus officinalis L., Thymus vulgaris L., Artemisia dracunculus L., Ficus carica L., Nigella sativa L., Olea europaea L. and Vitis vinifera L. are among the phytotherapies for diabetes. Although medicinal herbs are widely used for the prevention, control and treatment of diseases and are thought to be safe, medicinal herbs, especially during pregnancy or for children and other ill persons, can be toxic. Therefore, standard herbal medicine should be used [7]. Most modern chemicals and pharmaceuticals were obtained either directly or indirectly from medicinal plants and natural ingredients. Traditional medicine has been a productive resource for discovering new drug molecules for discovering effective drugs [8]. The emphasis of the World Health Organization on the gradual replacement of active chemical compounds with natural active compounds in the food, cosmetic and pharmaceutical industries has led various countries toward investing and planning for the production of nature-based products. Plants are rich and diverse sources of edible colors, antioxidants, flavors, aromatic substances, and extracts, and can provide nutritional, cosmetic, chemical, and pharmaceutical benefits to these active compounds.

\section{Authors' contribution}

All authors contributed equally to the manuscript.

\section{Conflicts of interest}

The authors declared no competing interests.

\section{Ethical considerations}

Ethical issues (including plagiarism, data fabrication, double publication and etc.) have been completely observed by author.

\section{Funding/Support}

None.

\section{References}

1. Roglic G, Norris SL. Medicines for treatment intensification in type 2 diabetes and type of insulin in type 1 and type 2 diabetes in low-resource settings: synopsis of the world health organization guidelines on second- and third-line medicines and type of insulin for the control of blood glucose levels in nonpregnant adults with diabetes mellitus. Ann Intern Med 2018; 169:394-397.

2. Capatina C, Paluzzi A, Mitchell R, Karavitaki N. Diabetes insipidus after traumatic brain injury. J Clin Med 2015; 4: 1448-62.

3. Varan A, Atas E, Aydin B, Yalçin B, Akyüz C, Kutluk T, et al. Evaluation of patients with intracranial tumors and central diabetes insipidus. Pediatr Hematol Oncol 2013; 30: 668-73.

4. Yang $\mathrm{Y}$ and Chan L. Monogenic Diabetes: What It Teaches Us on the Common Forms of Type 1 and Type 2 Diabetes. Endocr Rev 2016; 37(3): 190-222.

5. Kumar A, Aswal S, Chauhan A, Semwal RB, Kumar A, Semwal DK. Ethnomedicinal Investigation of Medicinal Plants of Chakrata Region (Uttarakhand) Used in the Traditional Medicine for Diabetes by Jaunsari Tribe. Nat Prod Bioprospect 2019; 9(3): 175200. 
6. Barkaoui M, Katiri A, Boubaker H, Msanda F. Ethnobotanical survey of medicinal plants used in the traditional treatment of diabetes in Chtouka Ait Baha and Tiznit (Western Anti-Atlas), Morocco. J. Ethnopharmacol 2017; 198: 338-350.

7. Nasri H, Shirzad H. Toxicity and safety of medicinal plants. J HerbMed Plarmacol. 2013; 2(2): 21-22.

8. Khodadadi S. Role of herbal medicine in boosting immune system. Immunopathol Persa 2015; 1(1): 01 